Łukasz Polniak

Wrocław

\title{
Mit armii gen. Berlinga w kinie wojennym PRL w latach 1960-1989
}

\begin{abstract}
Abstrakt: Artykuł prezentuje mit armii gen. Zygmunta Berlinga rozwijany w propagandzie i filmie PRL w latach sześćdziesiątych i siedemdziesiątych XX w. W tekście wskazano najważniejsze źródła omawianego mitu oraz formy jego artykulacji. Tekst prezentuje cztery główne elementy mitu: armię Berlinga jako armię narodową, obraz żołnierza, mit armii Berlinga jako mit zwycięstwa oraz mit armii Berlinga jako element mitu początku nowej państwowości.
\end{abstract}

Słow a kluczowe: mit, pamięć, propaganda, wojsko, wojna.

Abstract: The article discusses the myth of the army of General Zygmunt Berling developed in communist propaganda and in Polish movies of the 1960s and the 1970s. The text identifies the main source of this myth and the basic forms of its propagation. The four main elements of the myth are identified: Berling's Army as a national army, the soldier's image, the myth of Berling's Army as a fictional victory and the myth of Berling's Army as part of the fictional beginning of the new state.

Key w ords: myth, memory, propaganda, army, Zygmunt Berling, Polish People's Republic, World War Second.

\section{Geneza mitu armii gen. Berlinga}

Pojęcie mitu odnosi się do opisu świadomości wielkich grup społecznych, stąd też mit może być traktowany zarówno jako kategoria pamięci zbiorowej, służąca budowie i podtrzymywaniu spoistości określonej wspólnoty ludzkiej (np. narodu), jak również jako kategoria komunikacji społecznej wewnątrz 
określonej grupy ${ }^{1}$. Zdaniem Tadeusza Biernata „mit jest podsumowaniem jakiś wypadków czy procesów w społeczeństwie, podsumowaniem będącym w pewnym sensie wypaczeniem rzeczywistości, bazującym bardzo często na irracjonalnych, a nawet nadnaturalnych założeniach, lecz wcielających w życie $\mathrm{w}$ formie symbolicznej wartości czy wierzenia tego społeczeństwa"2. Jedna z kategorii stanowią mity polityczne, które można podzielić na mity powstałe w naturalny sposób, tj. jako irracjonalna reakcja społeczna na mające miejsce w rzeczywistości zdarzenia oraz na mity wykreowane w celowy i zaplanowany sposób $^{3}$. W XX w. w państwach totalitarnych i autorytarnych narzędziem upowszechniania mitów stały się systemy propagandowe, w tym radio, telewizja, prasa i film oraz podporządkowane władzy literatura i sztuka. Jak wskazuje Marcin Kula, nośnikami mitów politycznych mogą być w szczególności instytucje państwowe o rozbudowanej pamięci, takie jak wojsko i policja ${ }^{4}$. W przypadku wojska przechowuje ono pamięć nie tylko o wrogach, ale przede wszystkim o wodzach i dowódcach, poszczególnych jednostkach zbrojnych, indywidualnych bohaterach, miejscach bitew i potyczek oraz o klęskach i zwycięstwach ${ }^{5}$. Szczególną nośnością odznaczają się mity o charakterze narodowo-patriotycznym, organizujące pamięć i tożsamość wspólnot narodowych.

Wśród polskich mitów narodowych wskazać można m.in. mit państwowości polskiej, mit I Rzeczypospolitej, mit Polski jako „przedmurza chrześcijaństwa” i pokrewny mu mit Kresów Wschodnich ${ }^{6}$. Własne mity polityczne wytworzyła także państwowość PRL. Zdaniem Wojciecha Sokoła były to mit powszechnego entuzjazmu w latach 1944-1949; mit „bohaterskiej industrializacji” w latach 1949-1956; mit siermiężnego socjalizmu w latach 1956-1970; mit „budowy nowej Polski” w latach 1970-1980 oraz mit ,socjalistycznej odnowy i porozumienia" w latach 1980-19897. W polskiej mitologii narodowej szczególne miejsce zajmuje mit wojska i żołnierza, postrzeganych jako wyraz siły narodowej

\footnotetext{
${ }^{1}$ Kompleksowe omówienie pojęć, mitu i mitologizacji oraz różnych ujęć tematu zawiera praca: B. Szacka, Czas przeszły, pamięć, mit, Warszawa 2006. Na temat mitów zob. też: M. Eliade, Sacrum, mit, historia. Wybór esejów, wstęp M. Czerwiński, tłum. A. Tatarkiewicz, Warszawa 1993; J.P. Roux, Krew. Mity, symbole, rzeczywistośc, tłum. M. Perek, Kraków 1994; R. May, Błaganie o mit, tłum. B. Moderska, T. Zysk, Warszawa 1997; J.P. Roux, Krew. Mity i symbole, tłum. K. Marczewska, Warszawa 1998.

2 T. Biernat, Mit polityczny, Warszawa 1989, s. 26.

${ }^{3}$ Ibidem.

${ }^{4}$ M. Kula, Pamiętliwe instytucje, ruchy i systemy polityczne. Rzut oka historyka, „Kultura i Społeczeństwo" 2001, nr 3-4, s. 106.

${ }^{5}$ Ibidem. Zob. też: Wojna, pamięć i tożsamość. O bitwach i mitach bitewnych, red. J.M. Piskorski, Warszawa 2012.

${ }^{6}$ Polskie mity polityczne XIX i XX wieku, red. W. Wrzesiński, Wrocław 1994. Zob. też: Mity $i$ stereotypy $w$ dziejach Polski, red. J. Tazbir, Warszawa 1991; Ideologie, poglady, mity $w$ dziejach Polski i Europy XIX $i$ XX wieku. Studia historyczne, red. J. Topolski, W. Molik, K. Makowski, Poznań 1991.

${ }^{7}$ W. Sokół, Legitymizacja systemów politycznych, Lublin 1997, s. 158-170.
} 
oraz państwowotwórczej. Zdaniem Marii Janion był on osadzony w tradycji romantyzmu, a w toczonych wokół niego dyskusjach zazwyczaj przeciwstawiano go etosowi pracy pozytywnej ${ }^{8}$. Mit ten funkcjonował w czasach rozbiorów, natomiast w II Rzeczypospolitej znalazł swoją recepcję w programach obozu sanacji ${ }^{9}$. W okresie PRL, szczególnie po 1960 r., władze państwowe ponownie postanowiły sięgnąc do mitu wojska i żołnierza w celu wzmocnienia swojej legitymizacji oraz prób konsolidacji narodowej wokół pamięci o II wojnie światowej. Centralnym elementem tego mitu stały się I i II Armia Wojska Polskiego, które określam ogólnie jako armia gen. Berlinga.

Można przyjąć, iż pierwszym źródłem omawianego mitu jest tradycja polskiego kina wojennego z okresu II Rzeczypospolitej. W latach 1920-1939 nakręcono wiele filmów, których tematykę stanowiło upamiętnienie działań Legionów Polskich w czasie I wojny światowej, wydarzeń wojny polsko-bolszewickiej oraz bitwy warszawskiej $1920 \mathrm{r}$. Tematykę legionową poruszały m.in. takie filmy, jak: Szaleńcy (My, Pierwsza Brygada) (1928, reż. Leonard Buczkowski), Rok 1914 (1932, reż. Henryk Szaro), Śluby ułańskie (1934, reż. Juliusz Garden), Dodek na froncie (1935, reż. Michał Waszyński), natomiast tematykę wojny 1920 r.: Dla Ciebie, Polsko (1920, reż. Antoni Bednarczyk), Cud na Wista (1921, reż. Ryszard Bolesławski), Janko Zwycięzca (1921, reż. Gustaw Cybulski ps. „Jankowski”), Miłość przez ogień i krew (1924, reż. Jan Kucharski), Mogiła Nieznanego Żotnierza (1927, reż. Ryszard Ordyński), $Z$ dnia na dzień (1929, reż. Józef Lejtes), Gwiaździsta eskadra (1930, reż. L. Buczkowski), Krwawy wschód (1936, reż. Jan Nowina-Przybylski) ${ }^{10}$.

Drugie źródło omawianego mitu stanowi wzrost politycznej roli środowisk mundurowo-kombatanckich wywodzących się zarówno z szeregów dawnej Gwardii/ Armii Ludowej (tzw. partyzantów), jak również z I i II Armii WP w ZSRR na początku lat sześćdziesiątych. Nie wnikając w skomplikowane relacje między tymi grupami, warto przywołać postać płk. Zbigniewa Załuskiego, którego postrzegano jako wyraziciela poglądów środowisk mundurowo-kombatanckich ${ }^{11}$. W publikowanych przez siebie książkach głosił on konieczność ścisłego sojuszu polsko-radzieckiego, który traktował jako egzystencjalny dla państwa polskiego. Przekonanie to uzasadniał poglądem, iż w czasie wojny to właśnie ZSRR jako jedyne mocarstwo gwarantowało odrodzenie państwa polskiego (wobec nielojalności aliantów zachodnich), a w okresie powojennym jego trwanie w układzie międzynarodowym. Zdaniem Załuskiego armia Berlinga stanowiła rzeczywiste wypełnienie tego żywotnego sojuszu. Porównywał „czyn zbrojny” armii Berlinga z opowiedzeniem się Polaków po stronie Napoleona w XIX w. Doniosłe znaczenie nadawał bitwie pod Lenino,

\footnotetext{
${ }^{8}$ M. Janion, Płacz generała. Eseje o wojnie, Warszawa 2007.

${ }_{9}$ Ibidem, s. 33-34.

10 Ł.A. Plesnar, 100 filmów wojennych, Kraków 2012, s. 123.

${ }^{11}$ Ł. Polniak, Koncepcja unarodowienia komunizmu w historyczno-politycznej myśli Zbigniewa Zatuskiego, „Wrocławskie Studia Politologiczne” 2005, nr 5.
} 
dla której znajdował analogię w polskiej szarży pod Somosierra. Zdaniem Załuskiego była ona szczególnie potrzebna po wyjściu armii Andersa z ZSRR, co umożliwiło odzyskanie zaufania Stalina do Polaków. Partyjny ideolog przeciwstawiał armię Berlinga armii Andersa oraz Armii Krajowej. Twierdził, że wyłącznie działania I i II Armii WP stanowiły wyraz trafnej oceny sytuacji $\mathrm{w}$ okresie wojny oraz legitymizowały sojusz z ZSRR. W tym rozumieniu to właśnie armia Berlinga miała być „autentyczną” armią narodową ${ }^{12}$.

Trzecim źródłem wydaje się być ideologiczno-propagandowy impuls płynący ze Związku Radzieckiego, gdzie szeroko propagowano filmy i literaturę ukazująca apologetyczny obraz Armii Czerwonej oraz zwycięstwa nad faszyzmem. Jako przykłady „oficjalnych” produkcji wymienić można m.in. monumentalne dzieło Wyzwolenie (1969, reż. Jurij Ozierow), Blokada (1974, reż. Michaił Jerszow) o oblężeniu Leningradu, Oni walczyli za ojczyznę (1975, reż. Siergiej Bondarczuk) o walkach odwrotowych w 1942 r., Los generata (1974, reż. Jewgienij Karielow), Bitwa o Moskwę (1985, reż. J. Ozierow). Na przypomnienie zasługuje zapomniany w Polsce film Ozierowa, pt. Żotnierze wolności (1977), poświęcony roli rodzimych komunistów w poszczególnych krajach Europy Środkowej i Wschodniej w instalowaniu w nich władzy radzieckiej. W pierwszej i drugiej części filmu pojawia się tematyka polska. Ukazano w nich działalność PPR w latach 1943-1945 (m.in. postacie Bolesława Bieruta, Pawła Findera, Małgorzaty Fornalskiej oraz Piotra Jaroszewicza), rozmowy komunistów z Delegatura Rządu RP na Kraj, śmierć gen. Sikorskiego, rozmowy Mikołajczyka z Churchillem, Powstanie Warszawskie oraz I Armię WP usiłująca udzielić pomocy powstaniu. Kulminacyjną sceną filmu było pierwsze publiczne wystapienie przedstawicieli PKWN w lipcu 1944 r. na dziedzińcu Zamku Lubelskiego w scenerii 450 trumien Polaków pomordowanych przez Niemców ${ }^{13}$.

Za czwarte źródło omawianego mitu - o charakterze bezpośrednim można uznać Uchwałę Sekretariatu KC w sprawie kinematografii z 1960 r. Ponieważ była ona szczegółowo omawiana $\mathrm{w}$ literaturze przedmiotu, ograniczam się tylko do wymienienia trzech jej głównych założeń. Były to: potępienie Polskiej Szkoły Filmowej - a więc pośrednio także obecnego w niej obrazu wojska - za „niewspółgranie z celami socjalizmu”; nakaz czerpania tematyki i inspiracji z doświadczeń II wojny światowej; realizowanie filmów adresowanych do niższych warstw społecznych ${ }^{14}$. Można przyjąć, że

${ }^{12}$ Ibidem.

${ }^{13}$ Film początkowo był anonsowany w Polsce, pt. Komuniści. Zob. W. Rutkiewicz, Sprawa Polska w „Komunistach”, „Ekran” 1975, nr 30, s. 3-5; „Komuniści” na planie, „Ekran” 1975, nr 38, s. 12; „Komuniści”, „Film” 1975, s. 18-19.

${ }^{14}$ Pełny tekst Uchwały zawiera praca: Syndrom konformizmu? Kino polskie lat sześćdziesiqtych, red. T. Miczka, A. Madej, Katowice 1994, s. 27-34. Zob. też: M. Jankun-Dopartowa, Komitet Centralny zawraca kinematografie, w: Historia kina polskiego, red. T. Lubelski, K.J. Zarębski, Warszawa 2007, s. 111-113. 
dopiero zbieżność powyższych czterech elementów wpłynęła na rozwinięcie omawianego mitu.

\section{Film wojenny jako nośnik mitu armii gen. Berlinga}

Kino wojenne w PRL doczekało się już opracowań w literaturze przedmiotu ${ }^{15}$. W literaturze filmoznawczej film wojenny definiuje się jako ,jeden z najbardziej popularnych gatunków kina, film fabularny lub paradokumentalny zrealizowany w formie rekonstrukcji historycznej, widowisko filmowe osnute na autentycznych wydarzeniach i faktach zaczerpniętych $\mathrm{z}$ historii, bądź kreujące własną wojenną mitologię, którego zasadę konstrukcyjną i główny temat stanowią konflikt militarny i obrazy działań wojennych"16. Jako podgatunek filmu wojennego wymienia się niekiedy filmy batalistyczne rozumiane jako „wielkie widowiska stanowiące często drobiazgową rekonstrukcję autentycznych wydarzeń z historii najnowszej, najczęściej poszczególnych bitew lub operacji militarnych"17. Cechą filmów batalistycznych jest apologetyczny stosunek do opiewanych wydarzeń ${ }^{18}$.

Podstawowe kryterium doboru filmów analizowanych w niniejszym tekście stanowił fakt występowania w ich tematyce I lub II Armii WP. W tekście uwzględniono tylko filmy powstałe po 1960 r., a więc pod wpływem omawianej powyżej Uchwały KC. Szlakowi bojowemu armii gen. Berlinga poświęcone były następujące filmy: Kwiecień (1961, reż. Witold Lesiewicz, scen. Józef Hen), Nieznany (1964, reż. W. Lesiewicz, scen. J. Hen), Gdzie jest generał? (1964, reż. i scen. Tadeusz Chmielewski), Czterej pancerni i pies (1965-1969, reż. Konrad Nałęcki, scen. Janusz Przymanowski), Potem nastapi cisza (1966, reż. Janusz Morgenstern, scen. Zbigniew Safjan, J. Morgenstern), Kierunek Berlin (1969, reż. Jerzy Passendorfer, scen. Wojciech Żukrowski), Ostatnie dni (1969, reż. J. Passendorfer, scen. W. Żukrowski), Jarzębina Czerwona (1970, rė̇. Ewa i Czesław Petelscy, scen. Waldemar Kotowicz, E. i Cz. Petelscy), Album Polski (1970, reż. Jan Rybkowski, scen. Ryszard Frelek), Zasieki (1973, reż. Andrzej J. Piotrowski, scen. J. Przymanowski), Zwycięstwo (1975, reż. J. Passendorfer, scen. W. Żukrowski), W te dni przedwiosenne (1975, reż. Andrzej Konic, scen. Z. Safjan), Do krwi ostatniej (1978, reż. Jerzy Hoffman, scen. Z. Safjan). Społeczną rolę żołnierzy armii gen. Berlinga po 1945 r. omawiaja filmy: Ogniomistrz Kaleń (1960, reż. i scen. E. i Cz. Petelscy), Zerwany most (1963,

\footnotetext{
${ }_{15}$ M. Hendrykowska, Film polski wobec wojny i okupacji. Tematy, motywy, pytania, Poznań 2011; Kino polskie wobec II wojny światowej, red. P. Zwierzchowski, D. Mazur, M. Guzek, Bydgoszcz 2011; T. Lubelski, Historia kina polskiego. Twórcy, filmy, konteksty, Katowice 2009.

${ }^{16}$ M. Hendrykowski, Leksykon gatunków filmowych, Poznań-Wrocław 2001, s. 175.

17 J. Wojnicka, O. Katafiasz, Stownik wiedzy o filmie, Bielsko-Biała 2005, s. 374.

18 Ibidem.
} 
reż. J. Passendorfer, scen. Roman Bratny), Agnieszka 46 (1964, reż. Sylwester Chęciński, scen. Wilhelm Mach, Zdzisław Skowroński), Skapani w ogniu (1964, reż. J. Passendorfer, scen. W. Żukrowski), Rzeczpospolita babska (1969, reż. Hieronim Przybył, scen. Stanisława Drzewiecka, H. Przybył), Południk zero (1970, reż. Waldemar Podgórski, scen. Aleksander Ścibor-Rylski), Pułapka (1971, A.J. Piotrowski, scen. Bohdan Czeszko, Tadeusz Pietrzak, Jerzy Bednarczyk), Pobojowisko (1985, reż. i scen Jan Budkiewicz).

\section{Najważniejsze elementy mitu armii gen. Berlinga}

\section{a) Armia gen. Berlinga jako armia narodowa}

Ukazanie armii gen. Berlinga jako armii narodowej, w najszerszej perspektywie, wynikało z realizowanej przez cały okres PRL strategii unarodowienia panującej władzy, powojennej państwowości oraz związanych z nimi symboli. Marcin Zaremba unarodowienie opisywał jako długotrwały i zakrojony na szeroką skalę proces „nacjonalistycznej legitymizacji komunistycznej władzy”. Pisał on: „nacjonalizm był traktowany przez rządzący Polską Ludowa establishment jako szczególnie nośny i skuteczny, wręcz niezbędny środek, argument przeciwdziałający odrzuceniu przez społeczeństwo władzy komunistycznej jako «obcej». Dopiero po zmianie tej kwalifikacji na «swoją» rządzący mogli liczyć na uzyskanie akceptacji społeczeństwa ze strony zarówno grup dominujących, jak i uprzywilejowanych"19. Armia Berlinga jawiła się więc jako jeden z symboli władzy, który z jednej strony należało unarodowić, a z drugiej strony, ze względu na istniejący w społeczeństwie polskim wysoki prestiż munduru, nadawał się do wykorzystania jako element pozyskiwania łączności między władzą a narodem.

Dążenie do ukazania armii Berlinga jako armii narodowej stanowiło także odpowiedź na istniejące, przynajmniej w części społeczeństwa (i niezależnie od realiów historycznych), przekonanie, że była ona „wojskiem obcym” służącym obcemu mocarstwu. Obawy te wydają się znajdować odbicie w analizowanych tu filmach. W Potem nastapi cisza rozgrywa się następujacy dialog między byłym akowcem, który wstapił do armii Berlinga, a jego kolegami z konspiracji: „a więc wstapiłeś do tej armii? Tak, do pierwszej polskiej dywizji [chodzi o I Dywizję im. Tadeusza Kościuszki - Ł.P.]. Przymiotnik polski stał się ostatnio bardzo elastyczny [...] naszego wojska już nie ma!"'20 Podobne obawy pojawiały się w ustach samych żołnierzy Berlinga. W filmie Kwiecień dowódca pułku zwraca się do żołnierzy: „mamy rozkaz wiązać siły nieprzyjaciela i rozkaz ten wykonamy jak najlepiej, nie zniesiemy by mówili, że

${ }^{19}$ M. Zaremba, Komunizm, legitymizacja, nacjonalizm. Nacjonalistyczna legitymizacja władzy komunistycznej w Polsce, Warszawa 2001, s. 81.

${ }^{20}$ Wszystkie zawarte $\mathrm{w}$ tekście dialogi i wypowiedzi bohaterów filmowych zostały spisane z oryginalnych ścieżek dźwiękowych omawianych filmów. 
jesteśmy tym gorszym wojskiem polskim". Takich i wiele innych podobnych stwierdzeń można znaleźć w omawianych filmach, są one często wyrażane nie tylko za pomoca słów, ale także kontekstów sytuacyjnych.

Sądzę, iż próbę dotknięcia tematu antynomii między „,autentycznie” polska AK a „obcą" armią Berlinga stanowi cytowany film Potem nastapi cisza. Film porusza tematykę, która w $1966 \mathrm{r}$. była aktualna nie tylko dla przedstawicieli władzy i wojska wywodzacych się z armii Berlinga, ale także dla żyjących wciąż kombatantów AK, których w latach sześćdziesiątych próbowano pozyskiwać dla systemu (np. w ramach ZBoWiD). Temat filmu stanowią relacje między wkraczajacca do Polski armią Berlinga a pozostająca wciąż w konspiracji AK. Akcja filmu rozgrywa się w roku 1944 na ziemiach polskich. W jednym z oddziałów II Armii WP służy por. Kolski - dawny partyzant AK, który następnie wstępuje do armii Berlinga i przechodzi z nią szlak bojowy; obecnie jest już człowiekiem całkowicie lojalnym wobec wojska, w którym służy oraz wobec ustroju i wartości, które ono przynosi. Druga postać to por. Olewicz wcielony do armii Berlinga - jeszcze niedawno dowódca partyzantki AK. Po wkroczeniu oddziału do Krakowa okazuje się, że istnieje tam w zakonspirowanej formie dawny oddział AK, a w nim dawna dziewczyna i przyjaciele Kolskiego. Porozumienie między nimi nie jest jednak proste.

Równolegle do losów Kolskiego ukazane są dzieje por. Olewicza. Mimo iż stara się być lojalnym żołnierzem, co potwierdza w boju, jako były akowiec jest traktowany podejrzliwie i nieufnie przez nowych dowódców. Miara goryczy przelewa się, kiedy zostaje bezpodstawnie oskarżony o zabójstwo jednego z żołnierzy. Aby uniknąć aresztowania, Olewicz dezerteruje i udaje się do swoich przyjaciół z AK. Okazuje się, że są to Ci sami ludzie, których zna Kolski. W tym momencie w mieszkaniu pojawia się Kolski poszukujacy Olewicza, konspiratorzy odmawiaja jego wydania, dochodzi między nimi do bójki. W tym czasie Olewicz ucieka. Porozumienie między berlingowcami a akowcami okazuje się niemożliwe. Kolski prosi o przeniesienie na front. Istotna jest jednak postawa Olewicza, mimo ucieczki zwycięża w nim poczucie patriotyzmu i lojalności. W innym miejscu i pod zmienionym nazwiskiem ponownie wstępuje do armii Berlinga. Ostatecznie Kolski i Olewicz spotykaja się ponownie na froncie, walcząc ramię $\mathrm{w}$ ramię, obaj stają się bohaterami i ostatecznie obaj ponoszą śmieć w boju przeciwko Niemcom. Choć film przemilczał wiele aspektów związanych z rzeczywistymi represjami wobec akowców w latach czterdziestych, to jednak z finałowej wspólnej walki i śmierci poniesionej przez berlingowca i akowca można było wyciagnąć wniosek, że porozumienie między żołnierzami obu formacji jest możliwe oraz że obie formacje łączy fakt poświęcenia za Ojczyznę.

W ramach kreowania mitu armii Berlinga istniał także inny sposób ukazywania jej jako armii narodowej. Przedstawiano ja jako instytucję, w ramach której dochodziło do zespolenia różnych sił narodowych oraz do znoszenia przedwojennych podziałów narodowych i społecznych. W ten sposób 
w armii Berlinga realizował się ideał społecznego i narodowego solidaryzmu oraz jawiła się ona jako instytucja w najgłębszym stopniu wyrażająca interes narodu i państwa. Najszerzej armia Berlinga została ukazana w ten sposób w filmie Zasieki z 1973 r., element ten można znaleźć jednak prawie we wszystkich analizowanych tu filmach.

Film Zasieki przedstawiał I Dywizję im. T. Kościuszki, będąca ważnym elementem mitu armii Berlinga wykreowanym jako jej awangarda ${ }^{21}$. Ukazano tu skład społeczny armii Berlinga, przy czym każdą z postaci można uznać za symbol określonej grupy społecznej, narodowościowej lub orientacji politycznej. W jej skład wchodzili: dowódca pułku - ideowy komunista pochodzenia polskiego, lecz wychowany w Związku Radzieckim, były uczestnik wojny domowej w Hiszpanii; szef kompanii - starszy człowiek, w II Rzeczypospolitej oficer, obecnie z powodu wstydu za przegraną we wrześniu 1939 r. służy na własne życzenie jako szeregowy; autochton z Górnego Ślaska, który we wrześniu 1939 r. został przymusowo wcielony do Wehrmachtu, na froncie wschodnim zdezerterował i przeszedł na stronę Rosjan, podczas przesłuchania przez radzieckiego oficera stwierdza: „Ślązak to też Polak”; polski chłop, który przed wojną osiadł na rosyjskiej wsi, gdy otrzymuje powołanie do Armii Czerwonej, odprowadza go uroczyście cała wieś, w tym kombatanci z wojny polsko-bolszewickiej 1920 r. (sic!), rosyjskie kobiety śpiewaja pieśni ludowe w języku rosyjskim, jego stosunek do Związku Radzieckiego oddaja słowa: „przecież wiesz jacy ono sa, dzielili się nami ostatnią kromką chleba”; młody Polak wychowany w tradycji romantycznej (,jak słodko umierać za Ojczyznę") i jednocześnie ideowy komunista, w ZSRR mieszkał już przed wojna, we wrześniu 1939 r. walczył w WP, młody człowiek, przedwojenny inteligent i antykomunista (,Ty się Andrzej przed starym nie nadymaj, on się z faszystami bił jak Ty jeszcze paciorek odmawiałeś za Lwy Alkazaru”), który na skutek klęski we wrześniu 1939 r. zrozumiał swoje błędy i przeszedł na stronę komunistów. Pozwalam sobie na przytoczenie cytatów i omówień tego filmu, ponieważ - jak sądzę - dobrze oddają one zarówno specyfikę ówczesnej propagandy, jak i typowe środki perswazji stosowane w filmach tamtego okresu.

\section{b) Obraz żołnierza w micie armii gen. Berlinga}

Obraz żołnierza jest jednym z konstytutywnych elementów mitu armii gen. Berlinga. Podkreślić należy, iż wykreowana przez propagandę lat sześćdziesiątych i siedemdziesiątych postać żołnierza stała się jednym z najbardziej rozpoznawalnych toposów kultury masowej PRL. Stąd też analiza postaci

\footnotetext{
${ }^{21}$ Choć nie wynika to jasno z treści filmu, ówczesna prasa informowała, że przedstawia on I Dywizję im. T. Kościuszki w przededniu bitwy pod Lenino. Zob. E. Dolińska, Przed bitwa. O realizacji filmu „Zasieki”, „Film” 1973, nr 18, s. 7.
} 
żołnierza w odniesieniu do całości filmu wojennego w PRL dałaby znacznie szersze pole do porównań i możliwych nawiązań, tutaj jednak ograniczam się jedynie do filmów kreujących mit armii gen. Berlinga.

Analizę postaci żołnierza wypada zaczaćc od stwierdzenia, że w filmach ukazujących obraz armii Berlinga, na różnych etapach jej istnienia, zupełnie wyeliminowano postaci jej rzeczywistych dowódców. W żadnym filmie nie zapoznamy się z postaciami Zygmunta Berlinga, Michała „Roli” Żymierskiego, gen. Ludwika Popławskiego czy gen. Karola „Waltera” Świerczewskiego. Jedynym wyjątkiem jest tutaj serialowa wersja filmu Do krwi ostatniej z 1978 r., w której pojawia się epizodycznie gen. Berling. W wersji kinowej problem jego nieobecności został rozwiązany przez ukazanie Wandy Wasilewskiej i środowiska Związku Patriotów Polskich w ZSRR jako twórców wojska ${ }^{22}$. W przypadku gen. Berlinga można to wyjaśnić jego wykluczeniem z elity politycznej już w końcu lat czterdziestych. Karol Świerczewski pojawia się w filmie Żotnierz zwycięstwa z 1953 r., film ten nakręcony w okresie stalinizmu stawiał sobie jednak inne cele niż kreacja mitu armii Berlinga ${ }^{23}$. W omawianych filmach, z reguły, nie ukazywano postaci ani roli politycznej, obecnych w armii Berlinga oficerów politycznych, spośród których rekrutowała się cześć elit politycznych okresu stalinizmu ${ }^{24}$. Na tym wyczerpuje się obecność wojskowego kierownictwa omawianej armii w polskich filmach wojennych.

Głównymi postaciami mitu armii Berlinga są żołnierze-chłopi-gospodarze. $\mathrm{W}$ omawianych filmach żołnierze-inteligenci lub żołnierze-robotnicy występuja sporadycznie, nawet w kreacji postaci oficerów podkreśla się ich pochodzenie chłopskie. Zabieg ten wynika - jak sądzę - z co najmniej dwóch powodów. Po pierwsze, z przyczyn systemowo-ideologicznych - w interesie panujacego systemu leżało podkreślanie i podnoszenie znaczenia warstw niższych, w tym wypadku chłopów. Społeczeństwo polskie okresu PRL w pierwszym lub drugi pokoleniu wywodziło się z warstwy chłopskiej, więc podkreślenie znaczenie chłopstwa pozwalało łatwiej osiagnaćc władzy „łączność z narodem” oraz przedstawiać się jako władza „autentycznie” narodowa. Po drugie, wydaje się on wynikać z utrwalonego w tradycji polskiej mitu „narodowej

${ }^{22}$ Postać gen. Zygmunta Berlinga nie pojawiała się także przy okazji kolejnych i szeroko nagłaśnianych premier omawianych filmów ani tych traktowanych jako superprodukcje: Kierunek Berlin i Ostatnie dni, nie była przywoływana również w latach sześćdziesiątych, a więc w okresie największego nasilenia propagandy mundurowo-kombatanckiej. Po raz pierwszy postać Berlina wykorzystano przy okazji premiery filmu Do krwi ostatniej w roku 1978, nakręconego jako dzieło jubileuszowe z okazji „sześćdziesięciolecia odzyskania Niepodległości”. Berling pojawił się jedynie kilka razy na łamach prasy filmowej. Zob. Życiorys Polski: gen. Zygmunt Berling. Z gen. Z. Berlingiem rozmawiała Lidia Klimczak, „Ekran” 1978, nr 44, s. 3-5; W. Sokorski, Rozmowy z generatem, „Ekran” 1978, nr 41, s. 9.

${ }^{23}$ P. Zwierzchowski, Zapomniani bohaterowie. O bohaterach filmowych polskiego socrealizmu, Warszawa 2000, s. 135-142.

${ }^{24}$ Zob. np. T.A. Kisielewski, Janczarzy Berlinga. 1 Armia Wojska Polskiego 1943-1945, Poznań 2014. 
siły polskiego ludu" ${ }^{25}$. Jak pisała Teresa Kulak, mit ten upowszechniał się przez romantyczną poezję i literaturę, a w sensie politycznym jego kreatorem były elity szlacheckie o poglądach demokratyczno-rewolucyjnych ${ }^{26}$. Istotę tego mitu stanowiło uznanie ludu wiejskiego za główny nośnik siły i żywiołu narodowego, bez którego niemożliwa była skuteczna walka o odzyskanie niepodległości w okresie zaborów. Lud miał odznaczać się „mocą” i „czystościa” w przeciwieństwie do elit szlacheckich i inteligenckich skażonych obcymi naleciałościami. W XIX w. mit ten przeszedł ewolucję od idei zbrojnej walki powstańczej ludu przed rokiem 1848 do postulatu obrony posiadanej ziemi w końcu wieku ${ }^{27}$. Jeśli przyjąć powyższą interpretację, można zaryzykować twierdzenie, że w PRL po 1960 r. podjęto próbę nawiązania do tego mitu. W tej wersji chłopi-żołnierze byli główną siłą społeczną walcząca o wyzwolenie Polski spod okupacji niemieckiej, a w okresie powojennym budująca zręby nowej państwowości. Mit ten wzbogacony został o sojusz ze Związkiem Radzieckim, który w propagandzie PRL określano jako „historyczny”.

Podkreślenie znaczenia warstwy chłopskiej, w ramach omawianego mitu, oznaczało także wskazanie w rękach której warstwy społecznej znajdowały się w czasie wojny losy państwa i narodu. Warto zauważyć, iż nie odwołano się tutaj do obecnej w propagandzie okresu socrealizmu klasy robotniczej. Na marginesie wolno zauważyć, iż z biegiem czasu postać robotnika, zwłaszcza od połowy lat siedemdziesiątych (np. film Człowiek $z$ marmuru, 1977, reż. Andrzeja Wajda), nabierała kontekstu kontestacji panującego systemu. W latach sześćdziesiątych i później w celu eksponowania chłopskości i gospodarskości celowo dobierano aktorów odznaczających się wyraźnie chłopskim emploi. Archetypiczne postacie żołnierzy-chłopów stworzyli m.in. aktorzy Jerzy Turek, Wojciech Siemion (jako kpr. Naróg), Henryk Bąk oraz Wirgiliusz Gryń. Z postacią żołnierza-chłopa korespondują także patriarchalizm i familiarność, szczególnie akcentowane w przypadku żołnierzy starszych wiekiem. W filmie Ostatnie dni kpr. Naróg już w pierwszej scenie rozprawia o tym, jak „gospodarzył” i jak będzie „gospodarzył” po skończonej wojnie. W dalszej sekwencji Naróg spotyka na froncie swojego ojca, który podobnie jak on jest żołnierzem armii Berlinga, następnie już obaj: ojciec i syn - postacie uosabiające pokoleniową jedność - biorą udział w ostatecznym szturmie Berlina.

Zatrzymajmy się na dłużej przy pomijanych zazwyczaj toposach „gospodarza” i „gospodarności”, które stanowią integralną część postaci żołnierza. Dobrym przykładem jest tu film Kwiecień, którego akcja rozgrywa się wiosną 1945 r. Dowódca pułku otrzymuje rozkaz prowadzenia walk wiążących

\footnotetext{
${ }^{25}$ T. Kulak, Mit narodowej sity polskiego ludu (Fragment z dziejów polskiej myśli politycznej XIX i XX wieku), w: Polskie mity..., s. 153-166.

${ }^{26}$ Ibidem, s. 153 i n.

${ }^{27}$ Ibidem.
} 
nieprzyjaciela, ponieważ na Zachodzie zbliża się kończący wojnę szturm Berlina, budzi to obawę niepotrzebnych ofiar i sprzeciw wśród żołnierzy. W pułku służy żołnierz Anklewicz - starszy człowiek, weteran wojny 1920 r., ucieleśnienie typu żołnierza-gospodarza. Pod koniec wojny spotyka w lesie błąkające się bezpańskie krowy. Anklewicz dezerteruje z pułku, przygarniając bezpańskie zwierzęta. Odnaleziony przez żołnierzy usprawiedliwia się, że chciał odprowadzić zwierzęta do swojego gospodarstwa, aby je uratować. Dowódca pułku początkowo skazuje go na śmierć, ostatecznie po namowie innych żołnierzy decyduje się cofnąć karę. W przedstawionym epizodzie można dostrzec konfrontację etosu i obowiązku żołnierza z zupełnie obcym etosem chłopa. Fakt darowania życia Anklewiczowi przez dowódcę można odczytać jako koncesję uczynioną z etosu żołnierza na rzecz etosu chłopa-gospodarza. Etos gospodarza okazuje się silniejszy niż żołnierza, tym bardziej że wojna dobiega końca, a w czasie pokoju znowu potrzebni będą żywi chłopi-gospodarze, nie martwi żołnierze.

Etos gospodarza uwidacznia się również w aspektach terytorialnych. W filmie Zasieki jeden ze starszych wiekiem żołnierzy tak oto zwraca się do swoich kolegów: „po tamtej wojnie [z roku 1920 - Ł.P.] poszedłem z poznańskiego nad Zbrucz, po tej mogę i nad Odrę, tylko jak tam jest? Bo Marszałek dał wtenczas co obiecał, taki kawałek pszenno-buraczany, tylko nie powiedział jakich będę miał sąsiadów i nie powiedział, że moja zagroda jedna przeciwko całej ukraińskiej wsi”. Przytoczone powyżej epizody i cytaty przekonuja, że w micie armii Berlinga mamy w gruncie rzeczy do czynienia z kreacja żołnierzy, którzy „naprawdę” są chłopami i którzy „tylko” z konieczności i „tylko" tymczasowo, na okres wojny, zostali „przebrani” w żołnierskie mundury, aby zaraz po zakończonej wojnie ponownie powrócić do naturalnej roli gospodarzy.

\section{c) Mit armii gen. Berlinga jako mit zwycięstwa}

Pojęcie mitu zwycięstwa pojawiało się już w literaturze naukowej. Joanna Wawrzyniak łączyła je z aktywnością środowisk kombatanckich skupionych w ZBoWiD, pisząc: „retoryka zimnowojenna i jej dwie wielkie narracje «walka o pokój» i «front narodowy» wiązały się z mitem zwycięstwa nad faszyzmem mitem fundacyjnym i podstawowym dla całego systemu radzieckiego, także dla Polski Ludowej. Mitem, który uosabiał siłę i zwycięstwo, legitymizował nowy porządek polityczny w wymiarze międzynarodowym i wewnętrznym, a jednocześnie nakazywał ciagła mobilizację wskazując, że pełne zwycięstwo nie zostało jeszcze osiagnięte" ${ }^{28}$. Cytowana badaczka jako miejsca pamięci omawianego mitu wymieniła tereny byłych obozów koncentracyjnych oraz

${ }_{28}$ J. Wawrzyniak, ZBoWiD i pamięć drugiej wojny światowej 1949-1969, Warszawa 2009, s. 105. 
pola bitew z okresu wojny, a jako symbole wskazała postacie partyzantów oraz członków ruchu oporu ${ }^{29}$.

Chciałbym zwrócić uwagę na jeszcze jedną funkcję mitu zwycięstwa w filmie i propagandzie PRL. Polegała ona - jak sądzę - na dostarczaniu społeczeństwu polskiemu psychologicznej rekompensaty za poczucie klęski państwa polskiego w II wojnie światowej. Banałem będzie stwierdzenie, że gdyby losy wojny potoczyły się inaczej, a w latach 1944-1945 na ziemie II Rzeczypospolitej nie wkroczyła Armia Czerwona, a wraz z nia armia gen. Berlinga, powojenna Polska odbudowana zostałaby w innym kształcie ustrojowym i społecznym niż późniejsza PRL. W tym kontekście władze komunistyczne - chcąc czy nie - stawały się beneficjentami klęski wojennej II Rzeczypospolitej oraz jej elit przywódczych, cywilnych i wojskowych. Świadomość tego faktu stawiała komunistów w niezręcznej sytuacji wobec społeczeństwa oraz rodziła szereg problemów legitymizacyjnych utrudniających uznanie nowej władzy za „swoja”, szczególnie ze względu na jej genezę. Stąd też mit armii Berlinga, któremu twórcy propagandy nadali sens mitu zwycięstwa, pełnił funkcję psychologicznej rekompensaty wobec społeczeństwa polskiego - a przynajmniej jego części - krytycznie ustosunkowanego do władzy oraz jej elit przywódczych. Propagandowy mit ukazywał, iż wprawdzie władza powojenna nie zachowuje ciagłości państwowej i ideowej, posiada jednak legitymację do rządzenia, ponieważ jest władzą zwycięska, a sam fakt objęcia rządów stanowi rezultat dokonanego przez nia, „historycznego” oraz „największego w dziejach” zwycięstwa, jak określała to ówczesna propaganda ${ }^{30}$.

O tym, iż omawiany mit pełnił funkcję psychologicznej rekompensaty za dotychczasowe klęski, przekonują wypowiedzi zarówno bohaterów w filmach, jak i recenzentów, świadczące o odbiorze społecznym. W filmie Kwiecień dowódca pułku mówi do swoich podwładnych: „zwracają się do mnie z pretensjami jakbym to ja tą wojnę wymyślił. Tymczasem ona przyszła do nas i zrobiła z nas nędzarzy, bez przystani, bez rodzin, bez zapasowej pary spodni. Dostawaliśmy zawsze w skórę, bito nas w każdej dziedzinie, przegrywaliśmy każde powstanie, a ilu straciło wiarę w możliwość stworzenia państwowości, właśnie tu, na polskiej ziemi! Jeszcze bardziej niż całe głowy paru facetów potrzebne jest nam zwycięstwo, odzyskanie wiary we własna wartość". W okresie PRL mit zwycięskiej armii Berlinga miał właśnie tę wiare przywracać.

W 1968 r. recenzent Czterech pancernych i psa wyjaśniał przyczyny popularności serialu: „w filmie polskim najczęściej to myśmy dostawali w mordę i nam kradziono kiełbasę; nawet w zwycięskich pochodach na Zachód wlekliśmy za sobą tak wielki bagaż, iż z perspektywy tych krzywd największy

\footnotetext{
${ }^{29}$ Ibidem, s. $123-146$.

${ }^{30}$ Zob. np. W. Gomułka, Powrót na historyczne ziemie piastowskie największym zwycięstwem w dziejach Polski, Warszawa 1970.
} 
łuk triumfalny świata wydawać się mógł żałośnie mały [...] film wojenny wzbudził szalony głód zwycięstwa. Nie o sztandary na Reichstagu tu chodzi, lecz o powszechną u nas i dogłębnie w nas zakorzeniona, świadomość zwycięstwa, o moralną rekompensatę poniesionych krzywd. Film «Czterej pancerni» ugruntowuje tę świadomość, dostarcza rekompensaty. Oto «Rudy» na szlaku bojowym, wspaniały czołg. Oto prą na zachód dwie potężne, wspaniałe, bratnie armie, druzgocące siły nieprzyjaciela, nadające nowy bieg złośliwej historii. Każdy cios w szczękę wroga i każdy celny strzał są tu dobrym uczynkiem, bo to już nie tylko nasz odwet i nasze zwycięstwo, ale także akt sprawiedliwości dziejowej, im więcej tych aktów, tym mniej będzie musiała się rumienić historia, tym bardziej będziemy wierzyć w siebie. I tak «Czterej pancerni» graja na strunach narodowej duszy" ${ }^{31}$.

Warto w tym miejscu zauważyć, iż nośniku mitu zwycięstwa nie stanowiła np. cała seria filmów poświęconych partyzantce Gwardii i Armii Ludowej. Oczywiście partyzanci GL/ AL byli zwycięzcami w sensie politycznym, jednak poświęcone im filmy, jak choćby Barwy walki (1965) czy Botdyn (1982), po prostu nie zawieraja tak jednoznacznej symboliki zwycięstwa, a ich sens propagandowy wydaje się polegać na wykreowaniu mitu/ legendy GL/ AL oraz jej udziału w wojnie niż w upowszechnianiu mitu zwycięstwa ${ }^{32}$.

Dobrym przykładem na ukazanie armii Berlinga jako armii zwycięskiej jest film $W$ te dni przedwiosenne. Mowa tu o autentycznych wydarzeniach ze szlaku bojowego Brygady Kawalerii przy I Armii WP, czyli rzeczywistej szarży brygady konnej (wspólnie z czołgami) na umocnione pozycje niemieckie 1 III 1945 r. na Pomorzu. Mitotwórczy sens filmu dobrze oddaje wypowiedź płk. prof. dr. Emila Jadziaka, komendanta Wojskowego Instytutu Historycznego i jednocześnie konsultanta filmu: „szarża kawalerii pod Borujskiem była ostatnią historyczna szarżą kawalerii polskiej, formacji, która zapisała się piękną kartą w narodowej tradycji [...] polscy żołnierze walczyli we wszystkich częściach Pomorza, jak gdyby dokumentując swoją obecnością i przelaną krwią jego polski rodowód [...] przybliżyli oni znacznie ostateczną klęskę III Rzeszy. Zdobycie Borujska zapoczątkowało zwycięski marsz naszych żołnierzy w kierunku Bałtyku, a potem nad Odrę - ku Łabie i Berlinowi" ${ }^{3}$. Według prasowych recenzentów była to „ostatnia w Polsce szarża ludowych ułanów” ${ }^{34}$.

$\mathrm{Na}$ zwycięskim szlaku najważniejszą rolę odegrał główny bohater filmu, płk Kaszyba (jedna z niewielu postaci niereprezentujaccych warstwy chłopskiej). W filmie widzimy charakterystyczne zdarzenie, gdy do Kaszyby zgłasza się

31 B. Drozdowski, Kino na raty, „Kino” 1968, nr 4, s. 12-13.

32 Wydaje się, że filmy poświęcone partyzantce GL/ AL nie znalazły dotychczas całościowego omówienia w literaturze. Wyrażone tutaj opinie opieram na osobistej „lekturze” niemal wszystkich tych filmów oraz osobistych przemyśleniach. Są one oczywiście obarczone możliwością błędu.

${ }_{33}$ B. Zagroba, Szarża, „Film” 1975, nr 18, s. 7.

${ }^{34}$ Idem, Jaki piękny melodramat, „Film” 1975, nr 42, s. 9. 
partyzant z nieokreślonej jednostki partyzanckiej (na ręku jedynie biało-czerwona opaska) z prośba, aby ten zgodził się dowodzić atakiem na wycofujący się odział Wehrmachtu. Dowódca partyzancki motywuje to słowami: „ludzie rwą się do walki”. Kaszyba stanowczo odmawia, twierdząc, że partyzanci nie mają broni, a odział niemiecki jest wciąż groźny, w związku z czym rozkazuje poczekać do rana na regularne oddziały. Do partyzanta przyłącza się kierowca Kaszyby - postać nieprzypadkowa i symboliczna - młody chłopak, były powstaniec warszawski. Wspólnie z partyzantami łamią rozkaz i atakuja Niemców. W efekcie niepotrzebną śmierć ponosi kilku partyzantów. Analogia i przesłanie filmu wydają się czytelne: armia Berlinga reprezentuje siłę i doświadczenie oraz korzystne dla Polski sojusze, natomiast jej dowódcy odpowiedzialność, dojrzale pojęty patriotyzm, a nawet humanitaryzm. Postać młodego człowieka, kierowcy Kaszyby, można interpretować jako aluzję do Powstania Warszawskiego, natomiast „partyzant” prawdopodobnie wywodzi się z AK. W powyższej analogii próbowano dać do zrozumienia, iż siłę zwycięską i jedyną zdolna ponosić odpowiedzialność za kraj stanowi armia Berlinga, nie zaś „awanturnicza” Armia Krajowa i Powstanie Warszawskie.

O tym, iż kreacji armii Berlinga starano się nadać symbol zwycięstwa, przekonuje także tytuł filmu - Zwycięstwo. Obraz ten został zmontowany z fragmentów dwóch wcześniejszych filmów, tj. Kierunku Berlin i Ostatnich $d n i$, jako dzieło stanowiące oprawę obchodów 35-lecia PRL. Charakterystyczny dla środowisk wojskowo-kombatanckich symbol zwycięstwa zawierał także film Jarzębina Czerwona z 1969 r. Jak twierdził Krzysztof Kornacki, tytuł filmu nawiazywał do pieśni Czerwone maki na Monte Cassino, zwiąanej z walkami I Korpusu Polskiego gen. Andersa ${ }^{35}$. Film ten nadano w TVP 1 13 XII 1981 r. o godz. $20.00^{36}$, co świadczy, iż przedstawiciele środowiska wprowadzającego stan wojenny postrzegali jego symbolikę jako „własną”. Dzień wcześniej - także nieprzypadkowo - wyemitowano film Do krwi ostatniej, poświęcony formowaniu I Dywizji im. T. Kościuszki w Sielcach nad Oka oraz bitwie pod Lenino ${ }^{37}$. Podkreślić należy, iż symbolika zwycięskich (i nie tylko) bitew toczonych przez I i II Armię WP, takich jak: bitwa pod Lenino, forsowanie Bugu, walki o warszawską Pragę czy forsowanie Odry, pojawiała się $\mathrm{w}$ wielu analizowanych tu filmach. Ze względu na ograniczone rozmiary tekstu nie jest niestety możliwa ich szczegółowa prezentacja ${ }^{38}$.

Symbolem centralnym i wieńczaccym mit zwycięstwa było zdobycie Berlina. Wydarzeniu temu poświęcone zostały aż dwa filmy: Kierunek Berlin i Ostatnie dni. Akcja Ostatnich dni ukazuje współudział I Armii WP w zdobyciu Berlina. Pokonanie hitlerowskich Niemiec w ich własnej stolicy postrzegane

\footnotetext{
${ }^{35}$ K. Kornacki Kino generałów. Przypadek „Jarzębiny czerwonej”, w: Kino polskie..., s. 84.

${ }^{36}$ Ibidem, s. 89.

${ }^{37}$ Ibidem.

${ }^{38}$ Zob. M. Hendrykowska, op. cit., rozdz. XI.
} 
było jako akt „sprawiedliwości dziejowej”, który na dziesięciolecia zmienił geopolityczną mapę Europy i świata. W inwokacji do filmu podkreślano, że WP było trzecia siła koalicji hitlerowskiej walczaca na frontach świata przeciwko Niemcom. Oddano także hołd Polskim Siłom Zbrojnym na Zachodzie: wymieniono je z nazwy i opisano końcowy etap ich szlaku bojowego. Były to: I Dywizja Pancerna gen. Maczka oraz II Korpus Polski. Co charakterystyczne, nie wskazano nazwiska gen. Andersa ani gen. Berlinga, mimo iż podawano mniej znaczących dowódców.

Finałowa scena walk na ulicach Berlina została poprzedzona słowami lektora: „dokonała się sprawiedliwość dziejowa - wojna dosięgła stolicy Niemiec [...] nadeszła godzina obrachunku - polskie komendy słychać na ulicach Berlina". W kulminacyjnej scenie żołnierze polscy i radzieccy walcza obok siebie, co stanowi dobitny symbol braterstwa broni. Język rosyjski jest językiem sojuszników, język niemiecki - językiem wrogów. Film kończy się scena podejścia polskich i radzieckich żołnierzy pod Bramę Brandenburska, a z głośników rozlega się w języku niemieckim komunikat o kapitulacji Berlina. Pod Brama dochodzi do ostatecznego zbratania Polaków i Rosjan. W pewnym momencie na szczycie Bramy pojawiają się sztandary zwycięzców - polski i radziecki. Stojący przed bramą chłopi-żołnierze rzucają w górę czapki i płacza. Odtąd widz w powojennej Polsce miał zapamiętać, że Polacy walczyli i przegrywali nie tylko we wrześniu 1939 r. lub w Powstaniu Warszawskim, że zwyciężali nie tylko pod Moskwą (1610), pod Jasną Górą (1655), pod Wiedniem (1683) czy też pod Warszawą w 1920 r., ale że „największe polskie Zwycięstwo" odniesione zostało w sojuszu ze Związkiem Radzieckim, w Berlinie podczas walki przeciwko Niemcom. Twórcy filmu otrzymali trzy Nagrody I stopnia Ministra Obrony Narodowej.

\section{d) Mit armii gen. Berlinga jako mit początku nowej państwowości}

Propagandowa kreacja mitu armii gen. Berlinga nie kończyła się wraz z kulminacja jej szlaku bojowego w zdobytym Berlinie. Propagandyści tamtego okresu wyznaczyli żołnierzom doniosłą rolę społeczną i polityczna, a nawet narodowa, realizowaną w najwcześniejszym okresie instalowania powojennej państwowości. Żołnierze i kombatanci armii Berlinga zostali osadzeni w ramach szerszego „mitu początków nowej państwowości”, którego ramy czasowe można umownie określić na lata 1944-1947 $7^{39}$. Nie wnikając w szczegółowy opis mitu początku, którego bohaterami byli nie tylko berlingowcy, chciałbym przedstawić charakterystykę tych jego elementów, które dotycza bezpośrednio mitu żołnierza, a także kombatanta armii Berlinga.

\footnotetext{
${ }^{39}$ Ł. Polniak, Mit poczatku nowej państwowości jako kategoria legitymizacyjna w PRL na podstawie wybranych filmów fabularnych, „Zeszyty Naukowe WSO” 2011, nr 2. Zob. też: M. Hendrykowska, op. cit., rozdz. XV.
} 
Pierwszy element stanowiło ukazanie powojennej działalności żołnierzy na szerokim społecznym i politycznym tle tworzenia nowej państwowości w latach 1944-1947. Była to część mitu relatywnie najbliższa prawdzie historycznej (i chyba uczciwie pokazana jak na warunki lat sześćdziesiatych i siedemdziesiątych), mimo to ukazująca ówczesne realia w sposób wyidealizowany, a przynajmniej unikajacy drastycznych elementów życia społecznego $0^{40}$. Najczęściej przedstawiano obrazy ludności migrującej na nowe tereny lub powracającej do starych siedzib, przesiedleńców, częste były wizerunki ludzi powracających z obozów koncentracyjnych w rozpoznawalnych obozowych pasiakach. Inne motywy to powojenne zniszczenia, opustoszałe miasteczka oraz oczekiwania ludności cywilnej na nadejście nowej rzeczywistości. Ważnym elementem tła społecznego była destrukcyjna i antyspołeczna działalność różnego rodzaju grup i organizacji opozycyjnych w nowej rzeczywistości, m.in. podziemia akowskiego, Narodowych Sił Zbrojnych, szabrowników, Werwolfu oraz ukraińskich nacjonalistów. Godny uwagi choć rzadki - element propagandy stanowiło ukazanie problemu mniejszości narodowych, w szczególności polskich autochtonów na Ślasku (np. Skapani w ogniu, Pułapka), Kaszubów (Południk zero) oraz Ukraińców (Ogniomistrz Kaleń, Zerwany most).

Jednym z kluczowych elementem mitu było ukazanie żołnierzy armii Berlinga, obdarzonych szczególną charyzma, która predestynuje ich do odegrania roli przywódców, a często także obrońców społeczności lokalnych, w których się pojawiają lub przynajmniej wypełnienia ważnej funkcji w życiu tych społeczności ${ }^{41}$. Charyzma ta była naturalną konsekwencją doświadczeń wyniesionych z wojny oraz walki na szlaku Lenino-Berlin, przy czym doświadczenie to ukazywano nie tylko w kontekście wojenno-militarnym, ale jako proces „narodowego dojrzewania” jednostki oraz osobistego poświęcenia w walce o Polskę. Charyzmę żołnierzy Berlinga dostrzegała także ludność cywilna. Charakterystycznym obrazem jest scena wkraczania żołnierzy Berlinga do wyzwolonego miasteczka oraz entuzjastycznego powitania przez tłumy ludzi na ulicach (np. Ogniomistrz Kaleń). Inny to scena, w której ludzie ze stojącego na peronie tłumu przesiedleńców z ufnościa proszą żołnierzy o pomoc (np. Skapani w ogniu). Sceny te mają także sugerować, iż poparcie dla nowej władzy, uosobionej przez wojsko, istniało od początku i miało charakter masowy.

Kolejny element mitu stanowiło ukazanie armii Berlinga jako czynnika państwowotwórczego w najwcześniejszym okresie budowania nowej państwowości ${ }^{42}$. W propagandowym przedstawieniu wojsko było czynnikiem bardziej państwowotwórczym niż partia i władze cywilne, umieszczone zazwyczaj na

\footnotetext{
${ }^{40}$ Dla porównania warto sięgnąć do pracy: M. Zaremba, Wielka trwoga: Polska 1944-1947. Ludowa reakcja na kryzys, Warszawa 2012.

${ }^{41}$ Ł. Polniak, Mit poczatku..., s. 95.

${ }^{42}$ Ibidem.
} 
dalszym planie lub w ogóle nieobecne. W jubileuszowym filmie Album Polski, stanowiącym panoramę odbudowy i rozwoju PRL w latach 1944-1970, wojsko umieszczone zostało w pierwszej części, właśnie jako jedna z głównych instytucji, dzięki którym możliwe staje się odrodzenie państwa i społeczeństwa po pożodze wojennej. W jednej ze scen wkraczające polskie czołgi ratuja przed rozstrzelaniem przez Niemców grupę więźniów w symbolicznych obozowych pasiakach. W innej - symbolicznej - scenie żołnierze w mundurach, idąc równym szeregiem, obsiewaja puste pola z przewieszonej przez ramię chłopskiej płachty. Jakkolwiek wszystkie te wydarzenia w rzeczywistości mogły mieć miejsce w propagandowym przedstawieniu, wykorzystywano je w sposób symboliczny i mitotwórczy. Stale ukazywano żołnierzy i kombatantów w funkcji przywódców społeczności lokalnych (np. Rok pierwszy) lub występowali oni w roli ich obrońców przed zagrożeniem ze strony „band leśnych" (np. Pobojowisko), Werwolfu (np. Skapani w ogniu) lub szabrowników (np. Południk zero) ${ }^{43}$. Zawsze odznaczali się oni bohaterstwem - zdolnościa do poświęcenia się dla interesów ponadosobistych, w praktyce interesów wspólnot, w których żyli.

W kontekście charyzmy oraz państwowotwórczej roli żołnierzy i kombatantów armii Berlinga należy przywołać film Agnieszka 46, który w 1964 r. spotkał się ze zdecydowanym potępieniem ze strony środowisk wojskowo-kombatanckich. Film ten - w odczuciu krytyków - godził bezpośrednio w pamięć i etos środowiska osadników wojskowych z lat powojennych, a także - co ważniejsze - w społeczny wizerunek i prestiż wojska oraz pamięć o jego zasługach. Film przedstawia żołnierzy I Dywizji im. T. Kościuszki, którzy po wojnie osiedlają się na ziemiach zachodnich. Ukazana jest tu osada wojskowa zamieszkała przez zdemoralizowanych kombatantów utrzymujących się z przestępstw oraz zastraszania sąsiednich wsi. Mimo zakończenia wojny kultywuja w zdegenerowanej formie obyczaje wojskowe. Spoiwem łączacym ich społeczność jest - ukazana jako patologiczna - pamięć o wojennych wydarzeniach i ofiarach. Jednocześnie w eskapistyczny sposób odrzucaja współczesną rzeczywistość. Zmiany w życiu społeczności wojskowej przynosi dopiero przybycie młodej inteligentki - nauczycielki Agnieszki.

Przeciwko filmowi zaprotestowali rzadko zabierający głos gen. Zygmunt Berling na łamach utożsamianego z frakcja partyzancka dwutygodnika „Za Wolność i Lud” ${ }^{44}$ oraz wspominany już płk Załuski ${ }^{45}$. Berling pisał m.in.: „czy wolno zapominać, że w pierwszym, tak bardzo trudnym, okresie budowy naszego państwa, nie było dziedziny życia społecznego, w którym podpora nie byłoby wojsko? Czy wszystko to razem nie zobowiązuje społeczeństwa?

${ }^{43} \mathrm{Na}$ temat pojęcia „wroga” w PRL zob. K.W. Trembicka, Wrogowie w myśli politycznej Polskiej Zjednoczonej Partii Robotniczej, Lublin 2013.

${ }^{44}$ Z. Berling, W sprawie Agnieszki, „Za Wolność i Lud” 1965, nr 8, s. 8.

${ }^{45}$ Z. Załuski, Agnieszka i krytycy, „Za Wolność i Lud” 1965, nr 2, s. 8-11; Z. Załuski, Agnieszka i rzeczywistość, „Za Wolność i Lud” 1965, nr 3, s. 8-11. 
Jeżeli tak to czy ten film jest wyrazem tego zobowiązania? Już sam fakt wypuszczenia takiego film sugeruje coś bardzo złego w rozumieniu wartości całego wojska i na jego wielka, twórczą i bohaterska rolę w tworzeniu państwa rzuca ponury cień. Czy tak wolno? Chyba nie! Przecież to nieprawda!" 46 Pozytywny wizerunek osadnika wojskowego upowszechniła - jak można sądzić - komedia Rzeczpospolita babska.

Ważnym elementem kreowania zasług żołnierzy Berlinga było szerokie ukazanie ich roli w przyłączeniu i zagospodarowaniu Ziem Odzyskanych oraz terenów Bieszczad i pogranicza polsko-ukraińskiego ${ }^{47}$. Wynikało to nie tylko z potrzeb propagandy, ale także z „żywej pamięci” ciagle aktywnych w życiu społecznym i politycznym wojskowych uczestników wydarzeń na tych terenach. Pozwolę sobie w tym miejscu przytoczyć pokrótce treść kilku filmów, których akcja rozgrywała się na tych terenach, nie tylko po to, aby udokumentować wysiłek, jaki propaganda włożyła w ukazanie pozytywnej roli żołnierzy, ale także po to, by uzasadnić wcześniejsze tezy dotyczące mitu armii Berlinga. Jak wspomniałem, wszystkie filmy omawiane w tej części artykułu rozgrywają się na ziemiach zachodnich i północnych lub na „nowych kresach wschodnich”. Centralne obszary Polski cieszyły się mniejszym uznaniem ówczesnych propagandystów.

Sztandarowym filmem epoki sa Skapani w ogniu ${ }^{48}$. Żołnierz armii Berlinga tuż po wojnie zostaje $\mathrm{w}$ ramach obowiązków służbowych skierowany na Ślask. Spełnia tam rolę rozjemcy w konflikcie między polskimi autochtonami a przybywającymi z głębi Polski cywilnymi osadnikami oraz biorącymi ich stronę funkcjonariuszami Urzędu Bezpieczeństwa. Z konieczności staje się także obrońca tworzącej się społeczności przed atakami niemieckiego Werwolfu. W filmie występuje także kpr. Naróg, znany z filmów Kierunek Berlin oraz Ostatnie dni, przez co „mit początku” zyskuje ciagłość z obrazem szlaku bojowego Lenino-Berlin. Stosunkom narodowościowym na Górnym Śląsku poświęcony został także ciekawy, choć obecnie prawie zapomniany, film Pułapka z 1971 r. Jego wymowa była dużo bardziej nacjonalistyczna. Oficer armii Berlinga, z pochodzenia Ślązak, polski autochton, przybywa na Górny Ślask do swojego rodzinnego miasteczka, aby jako oficer WP objąć dowództwo garnizonu. Szybko zostaje poddany presji ze strony pozostałej tam ludności niemieckiej, która postrzega go jako „swojego” i namawia do dezercji z wojska. Presję wzmacnia szantaż ze strony działającego w okolicach Werwolfu. Sytuacja, w której zostaje postawiony nasz bohater, przypomina „sprawdzian narodowej lojalności”, w którym musi wybierać między więziami rodzinnymi i sąsiedzkimi a lojalnością narodową i państwową. Bohater filmu

${ }^{46}$ Z. Berling, op. cit., s. 8.

${ }^{47}$ Zob. G. Motyka, W kręgu „Łun w Bieszczadach”. Szkice z najnowszej historii polskich Bieszczad, Warszawa 2009; J. Zajdel, Filmowy obraz Polski powojennej, w: Syndrom konformizmu..., s. 106-120.

${ }^{48}$ J. Zajdel, op. cit., s. 106-120. 
wychodzi ze sprawdzianu obronną ręka, co podkreśla siłę polskich więzi narodowych na tych terenach oraz rolę wojska jako siły państwowotwórczej. $\mathrm{Na}$ ziemiach północnych rozgrywa się akcja filmu Pobojowisko. Zasłużony kapitan armii Berlinga - Łanowicki przyjeżdża do nadmorskiego miasteczka na Pomorzu, aby podratować zdrowie. Szybko okazuje się, że działa w tym miejscu nieokreślona z nazwy „banda” organizująca „nielegalny szlak przerzutowy na Zachód” oraz terroryzująca ludność miasteczka (zabija m.in. lokalnego komendanta milicji). Charakterystyczne, iż choć nasz bohater nie musi tego robić, angażuje się w zakończoną sukcesem walkę z podziemiem, wchodząc tym samym w rolę obrońcy społeczności lokalnej. W filmie ukazana jest również prospołeczna rola wojska m.in. rozminowujacego lokalny port. $\mathrm{Na}$ ziemiach zachodnich rozgrywa się także akcja wspomnianej już komedii Rzeczpospolita babska.

Najsłynniejszym filmem dotyczącym roli wojska w konflikcie polsko-ukraińskim jest Ogniomistrz Kaleń, obejmujący wydarzenia już po zakończeniu wojny na terenie Bieszczad ${ }^{49}$. Gdy w Polsce trwa powojenna odbudowa, Kaleń zostaje oddelegowany na te tereny jako żołnierz, aby walczyć z ukraińskim nacjonalistami z Ukraińskiej Powstańczej Armii oraz Polakami z NSZ. Kaleń ponosi bohaterska śmierć w imię wspólnej sprawy, jaką jest przywrócenie państwowości polskiej na tych terenach ${ }^{50}$. Film można odczytywać jako apologetyczny obraz zaangażowania wojska w rozwiązanie konfliktu polsko-ukraińskiego oraz jego zasług w tej dziedzinie. Podobnie w Bieszczadach rozgrywa się akcja Zerwanego mostu. W latach czterdziestych por. Mosur bierze udział w krwawych walkach z partyzantką UPA, co skutkuje represjami w okresie stalinowskim. Po zwolnieniu z więzienia wraca na te tereny, aby uczestniczyć w ich zagospodarowaniu jako inżynier. Czy film zawiera przesłanie, iż zasłużeni żołnierze Berlinga, podobnie jak w latach czterdziestych brali odpowiedzialność za Polskę i czynnie walczyli o jej granice, tak i współcześnie moga - a nawet powinni! - czynnie angażować się w życie społeczne.

Opisane powyżej główne elementy mitu armii Berlinga nie wyczerpuja oczywiście całkowitej jego charakterystyki. Można wskazać zapewne jeszcze takie elementy, jak proradzieckość, obecny w niektórych filmach wzór dowódcy, sens śmierci i ponoszonych ofiar, obraz wojny lub też antyniemieckość traktowana jako program polityczny. Mówiąc o micie armii Berlinga, warto także zadać pytanie o jego odbiór społeczny oraz trwałość? Niestety odpowiedzi na te pytania nie sa możliwe bez pogłębionych studiów nad opiniami i świadomością społeczeństwa w omawianym okresie. Analiza taka wykracza poza skromne cele niniejszego artykułu. Można jednak zaryzykować twierdzenie,

${ }^{49}$ G. Motyka, op. cit., s. 17-48, 95-122.

${ }^{50} \mathrm{Na}$ temat śmierci bohaterów w mitach zob. P. Zwierzchowski, Śmierć założycielska. Pamięć, tożsamość, propaganda, w: idem, Spektakl i ideologia. Szkice o filmowych wyobrażeniach śmieci heroicznej, Kraków 2006, s. 95-133. 
iż omawiany mit przyczyniał się do wzrostu społecznego prestiżu armii Berlinga, jak również wojska jako instytucji społecznej. Co do trwałości mitu uprawnione wydaje się twierdzenie, że jego żywotność skończyła się wraz ze zmianą ustroju w roku 1989 oraz zanikiem jego politycznej inspiracji.

\section{Streszczenie}

Artykuł prezentuje mit armii gen. Zygmunta Berlinga rozwijany w propagandzie i filmie PRL w latach sześćdziesiątych i siedemdziesiątych XX w. W tekście wskazano najważniejsze źródła omawianego mitu oraz formy jego artykulacji. Tekst prezentuje cztery główne elementy mitu: armię Berlinga jako armię narodowa, obraz żołnierza, mit armii Berlinga jako mit zwycięstwa oraz mit armii Berlinga jako element mitu początku nowej państwowości. Artykuł prezentuje polityczno-historyczną oraz kulturową genezę mitu armii Berlinga.

\section{The myth of Gen. Berling in the war movies of the Polish People's Republic after 1960}

The article discusses the myth of the army of General Zygmunt Berling developed in communist propaganda and in Polish movies of the 1960s and the 1970s. The text identifies the main source of this myth and the basic forms of its propagation. The four main elements of the myth are identified: Berling's Army as a national army, the soldier's image, the myth of Berling's Army as a fictional victory and the myth of Berling's Army as part of the fictional beginning of the new state.

\section{Bibliografia}

Biernat T., Mit polityczny, Warszawa 1989.

Eliade M., Sacrum, mit, historia. Wybór esejów, wstęp M. Czerwiński, tłum. A. Tatarkiewicz, Warszawa 1993.

Hendrykowska M., Film polski wobec wojny i okupacji. Tematy, motywy, pytania, Poznań 2011. Hendrykowski M., Leksykon gatunków filmowych, Poznań-Wrocław 2001.

Ideologie, poglady, mity $w$ dziejach Polski i Europy XIX $i$ XX wieku. Studia historyczne, red. J. Topolski, W. Molik, K. Makowski, Poznań 1991.

Janion M., Płacz generała. Eseje o wojnie, Warszawa 2007.

Kisielewski T.A., Janczarzy Berlinga. 1 Armia Wojska Polskiego 1943-1945, Poznań 2014.

Kulak T., Mit narodowej sity polskiego ludu (Fragment z dziejów polskiej myśli politycznej XIX i XX wieku), w: Polskie mity polityczne XIX $i$ XX wieku, red. W. Wrzesiński, Wrocław 1994.

Mity i stereotypy $w$ dziejach Polski, red. J. Tazbir, Warszawa 1991.

Motyka G., W kręgu „Łun w Bieszczadach”. Szkice z najnowszej historii polskich Bieszczad, Warszawa 2009.

Plesnar Ł.A., 100 filmów wojennych, Kraków 2002.

Polniak Ł., Koncepcja unarodowienia komunizmu w historyczno-politycznej myśli Zbigniewa Zatuskiego, „Wrocławskie Studia Politologiczne” 2005, nr 5.

Syndrom konformizmu? Kino polskie lat sześćdziesiatych, red. T. Miczka, A. Madej, Katowice 1994. 
Trembicka W.K., Wrogowie w myśli politycznej Polskiej Zjednoczonej Partii Robotniczej, Lublin 2013.

Wawrzyniak J., ZBoWiD i pamięć drugiej wojny światowej 1949-1969, Warszawa 2009.

Wojna, pamieć i tożsamość. O bitwach i mitach bitewnych, red. J.M. Piskorski, Warszawa 2012. Zajdel J., Filmowy obraz Polski powojennej, w: Syndrom konformizmu? Kino polskie lat sześćdziesiatych, red. T. Miczka, A. Madej, Katowice 1994.

Zaremba M., Komunizm, legitymizacja, nacjonalizm. Nacjonalistyczna legitymizacja władzy komunistycznej w Polsce, Warszawa 2001.

Zaremba M., Wielka trwoga: Polska 1944-1947. Ludowa reakcja na kryzys, Warszawa 2012.

Zwierzchowski P., Spektakl i ideologia. Szkice o filmowych wyobrażeniach śmieci heroicznej, Kraków 2006.

Zwierzchowski P., Zapomniani bohaterowie. O bohaterach filmowych polskiego socrealizmu, Warszawa 2000.

Biogram: Lukasz Polniak - dr, absolwent Instytutu Politologii na Uniwersytecie Wrocławskim; adiunkt w Katedrze Nauk Społecznych i Humanistycznych w Wyższej Szkole Bankowej we Wrocławiu. Zajmuje się dziejami Polski w XX wieku oraz zagadnieniami bezpieczeństwa narodowego. Autor pracy Patriotyzm wojskowy w PRL w latach 1956-1989. Publikował m.in. w „Dziejach Najnowszych”. E- m a il: lukaszpolniak@gmail.com. 